\section{MANAJEMEN STRATEGIK TEORI DAN IMPLEMENTASI}

Dalam bidang ekonomi khususnya di lingkungan bisnis yang mengembangkan manajemen secara teoritis dan praktis, Manajemen Strategik telah cukup lama dikenal dan dikembangkan. Hakikat dari strategi dan kebijakan bisnis akan bisa diraih melalui pemahaman secara mendalam tentang definisi yang dikemukakan oleh berbagai pakar. Sehingga dapat memberikan kajian-kajian secara sistematis dalam pembelajaran manajemen strategik di ruang kelas. Strategi dan kebijakan bisnis merupakan keputusan yang dibuat pada level manajemen puncak. Keputusan yang bersifat menyeluruh ini akan mendasari berbagai keputusan yang bersifat strategis dan tentunya sangat memerlukan kecermatan dalam merumuskan ataupun menjabarkannya. Dengan merumuskan strategi, berarti perusahaan telah membuat formulasi tentang apa yang harus dilakukan dalam bisnis. Penjabarannya diperlukan agar strategi dan kebijakan tersebut lebih mudah untuk diaplikasikan. Dalam pengertian umum, istilah manajemen strategi dan kebijakan bisnis sering menjadi rancu sehingga Buku ini diharapkan dapat memberikan penjelasan strategi korporat (strategi pada level puncak perusahaan) dan strategi fungsional di bidang pemasaran. Apalagi, intensitas topik yang disajikan di berbagai media massa Indonesia memang lebih banyak berbicara tentang strategi pemasaran daripada strategi pada level manajemen puncak. Buku ini dilengkapi dengan gambaran secara menyeluruh tentang konsep manajemen strategi dan kebijakan bisnis dalam perspektif pemikiran yang dikemukakan oleh berbagai pakar kebijakan bisnis. Implementasi Manajemen Strategik di lingkungan organisasi bidang bisnis didasari oleh falsafah yang berisi nilai-nilai persaingan bebas antar organisasi bisnis sejenis, melalui pendayagunaan semua sumber yang dimiliki untuk mencapai tujuan yang bersifat strategik. Tujuan tersebut adalah mempertahankan dan mengembangkan eksistensi masing-masing untuk jangka waktu panjang, melalui kemampuan meraih laba kompetitif secara berkelanjutan. Di era revolusi industry 4.0 ini, diharapkan dengan buku ini memberi wawasan dalam melihat berbagai peta persaingan dalam berbagai organisasi. Sehingga sangat penting memahami pengelolaan organisasi dengan pendekatann manajemen strategik dalam rangka mengoptimalkan alternatif-alternatif strategi dalam mencapai tujuan organisasi bukan hanya pada tataran jangka pendek dan menengah tetapi sampai pada jangka panjang.
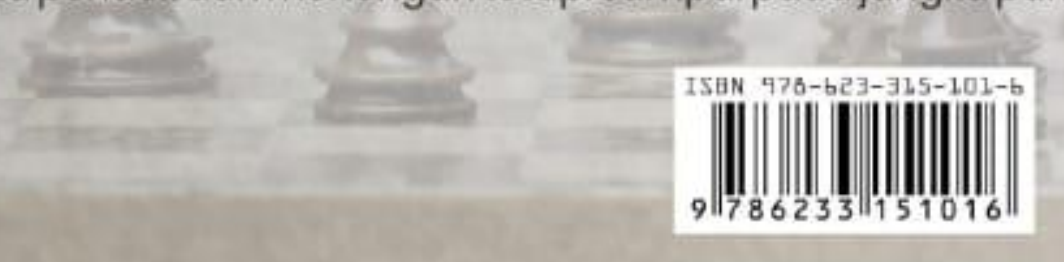

Opan Arifudin, S.Pd.,M.Pd.,CBOA.,CSRP

Rahman Tanjung, SE.,MM

Yayan Sofyan, SE.,MM

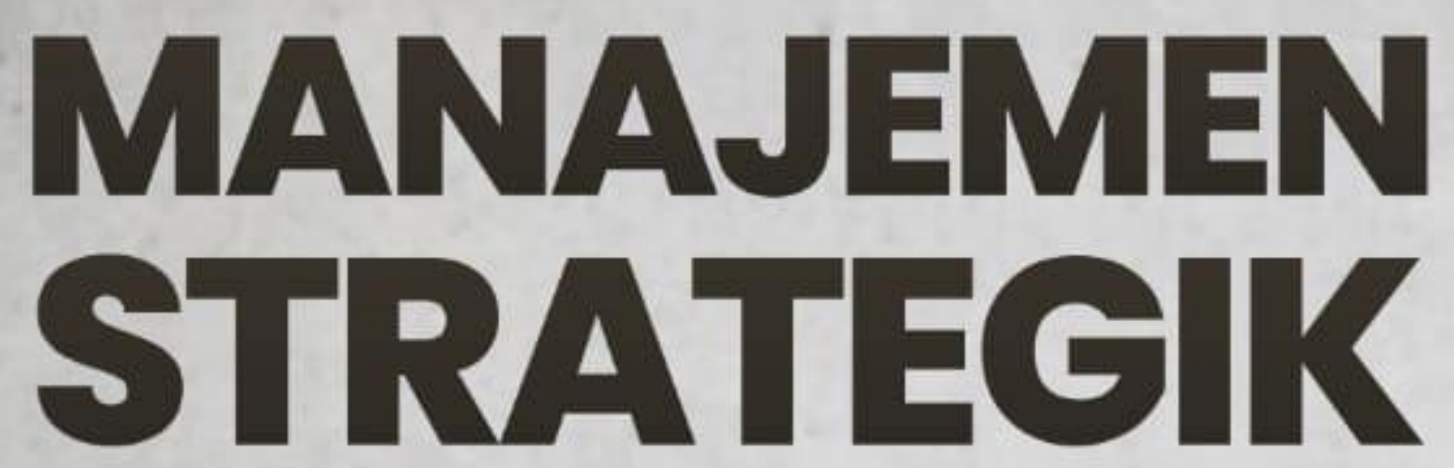

TEORI DAN IMPLEMENTASI

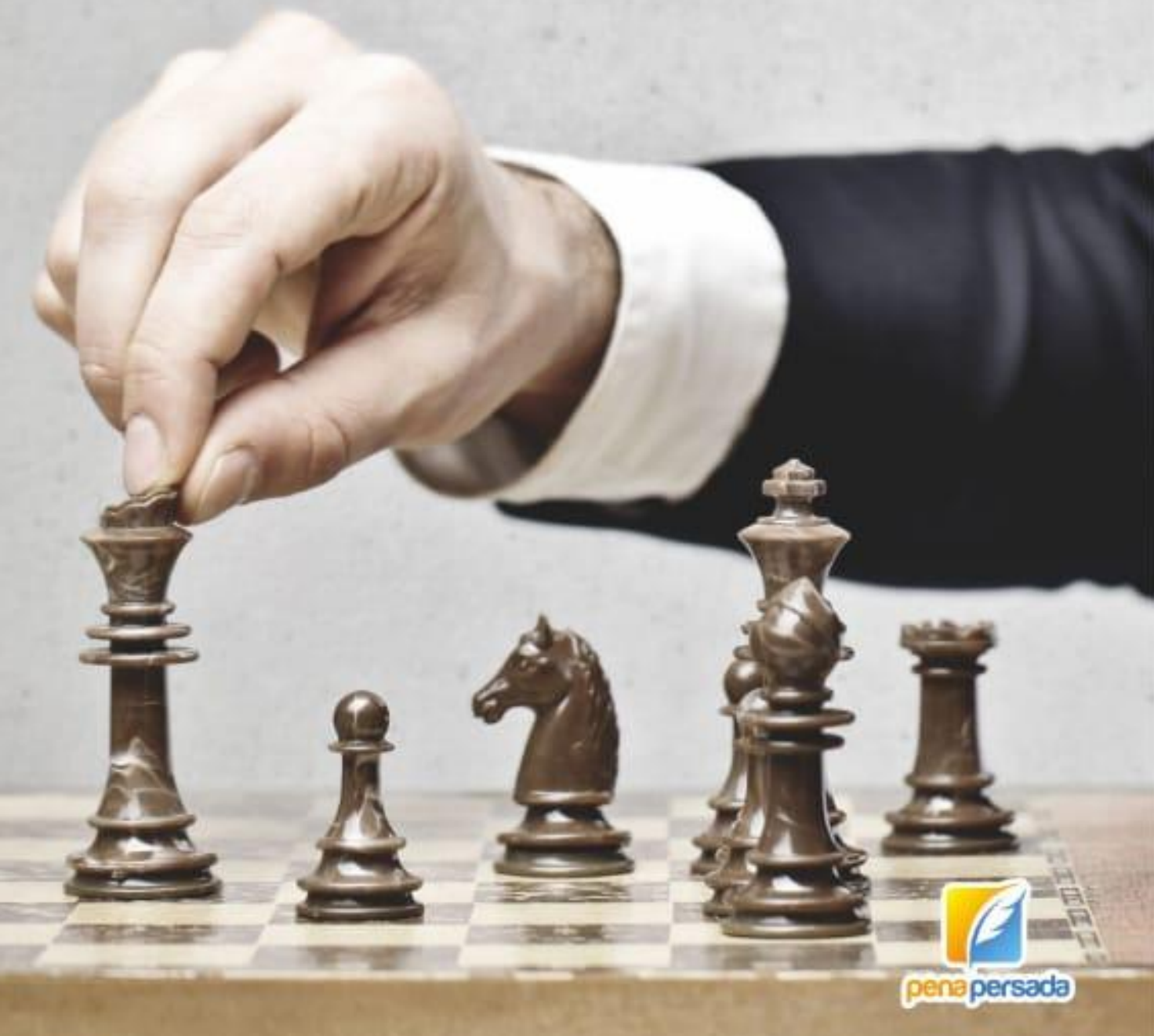




\title{
MANAJEMEN STRATEGIK TEORI DAN IMPLEMENTASI
}

\author{
OPAN ARIFUDIN, S.Pd., M.Pd., CBOA., CSRP \\ RAHMAN TANJUNG, SE., MM \\ YAYAN SOFYAN, SE., MM
}

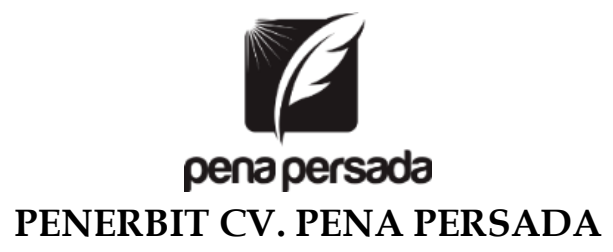




\title{
MANAJEMEN STRATEGIK \\ TEORI DAN IMPLEMENTASI
}

\author{
Penulis: \\ Opan Arifudin, S.Pd.,M.Pd.,CBOA.,CSRP \\ Rahman Tanjung, SE.,MM \\ Yayan Sofyan, SE.,MM \\ ISBN : 978-623-315-101-6
}

Design Cover :

Retnani Nur Briliant

Layout :

Eka Safitry

\section{Penerbit CV. Pena Persada}

Redaksi :

Jl. Gerilya No. 292 Purwokerto Selatan, Kab. Banyumas

Jawa Tengah

Email : penerbit.penapersada@gmail.com

Website : penapersada.com Phone : (0281) 7771388

Anggota IKAPI

All right reserved

Cetakan pertama : 2020

Hak Cipta dilindungi oleh undang-undang. Dilarang memperbanyak karya tulis ini dalam bentuk apapun tanpa izin penerbit 


\section{KATA PENGANTAR}

Segala puji dan syukur Penulis panjatkan ke hadirat Allah SWT., karena hanya dengan rahmat dan ridho-Nya, Penulis dapat menyelesaikan penulisan buku yang berjudul "Manajemen Strategik (Teori dan Implementasi) ".

Penulisan buku ini merupakan salah satu penunjang dalam menyelenggarakan proses pembelajaran di semua fakultas atau program studi sebagai bahan ajar mahasiswa pada mata kuliah Manajemen Strategik.

Buku ini diharapkan dapat memberikan formulasi terkait pembelajaran pada mata kuliah "Manajemen Strategik" karena memuat secara komprehensif teori-teori manajemen strategic dan implementasinya serta memberikan gambaran pada strategi samudera biru (Blue Ocean Strategy).

Penulis menyadari bahwa dalam penulisan buku ini masih jauh dari sempurna. Untuk itu, Penulis mengharapkan kritik dan saran yang membangun dari para pembaca sekalian, agar buku ini bisa menjadi lebih baik lagi.

Terima kasih kepada semua pihak yang telah membantu dalam penulisan buku ini. Penulis berharap, buku ini dapat bermanfaat khususnya untuk para mahasiswa dan umumnya untuk para pembaca sekalian. Aamiin.

Bandung, 4 Oktober 2020

\section{Penulis}




\section{DAFTAR ISI}

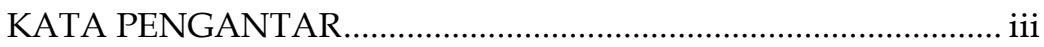

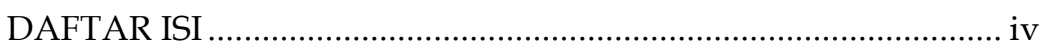

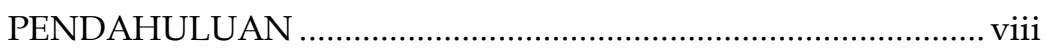

BAB I Ruang Lingkup dan Kebijakan Manajemen Strategik.....1

A. Pengertian Manajemen Strategik..............................................1

B. Proses Manajemen Strategik ................................................10

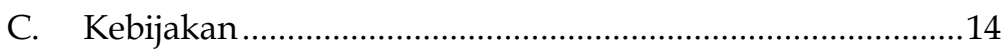

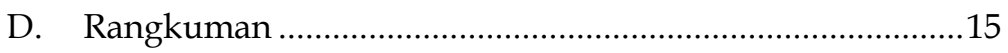

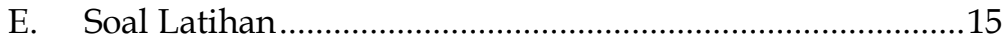

BAB II Prinsip Manajamen Strategik dan Model Manajemen

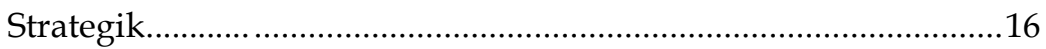

A. Prinsip Manajemen Strategik ..............................................17

B. Formulasi dan Tahapan Model Manajemen Strategik .......19

C. Karakteristik Manajemen Strategik ........................................21

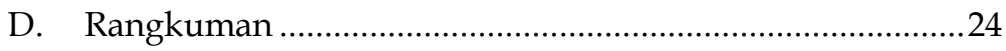

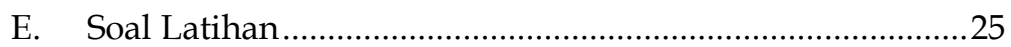

BAB III Manfaat dan Tujuan Manajemen Strategik ....................26

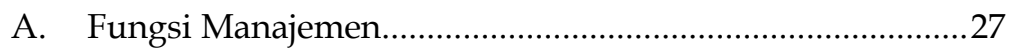

B. Fungsi Manajemen Strategik .................................................34

C. Manfaat Manajemen Strategik ...................................................35

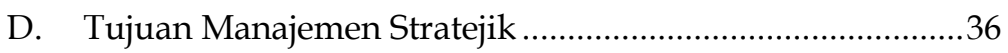

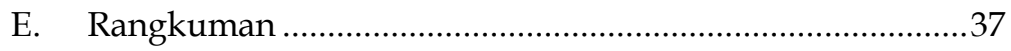

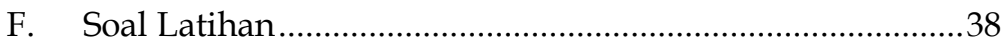

BAB IV Formulasi Tingkatan Strategik ..........................................

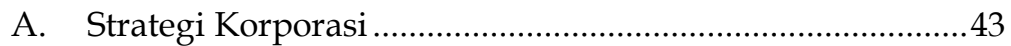




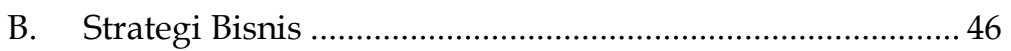

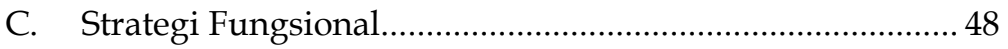

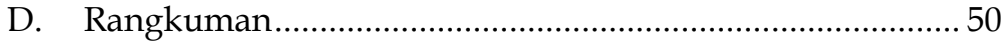

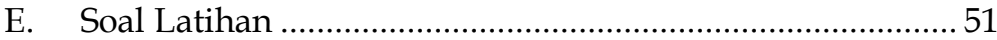

BAB V Analisis Lingkungan Usaha Dan SWOT Analysis : Analisis Industri Dan Pesaing........................................................ 52

A. Analisis Situasi Menggunakan SWOT …………………...... 55

B. Analisis Lingkungan Menggunakan Metode Porter ........... 58

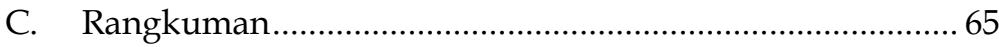

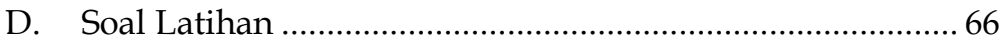

BAB VI Visi Misi dan Strategi Bisnis/Organisasi ........................ 67

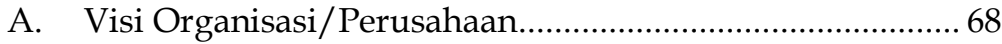

B. Misi Organisasi/Perusahaan.................................................... 70

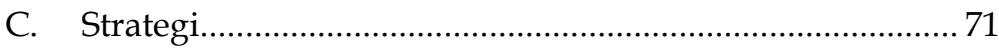

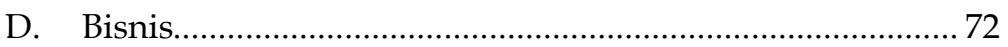

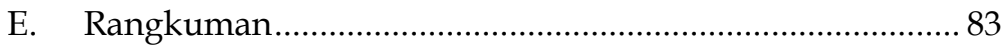

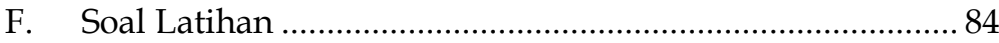

BAB VII Implementasi Strategi Pada Produk Perusahaan ........... 85

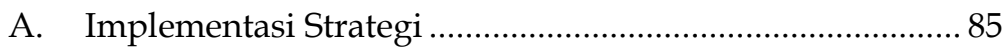

B. Komponen-Komponen Strategi …………………................ 87

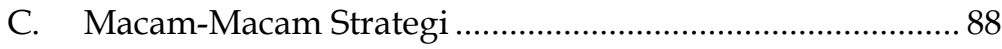

D. Pengembangan Produk........................................................ 93

E. Strategi Pengembangan Produk............................................ 95

F. Tahap Proses Pengembangan Produk Baru......................... 95

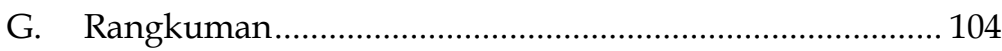

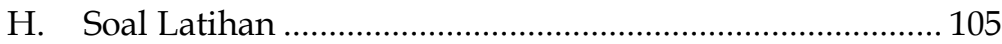

BAB VIII Stratejik Dalam Praktek (In Action) ............................ 106 
A. Strategik Generik ..............................................................106

B. Tahap-tahap dalam proses manajemen strategik .............109

C. Analisis Kompetitif Model Lima Kekuatan Porter ............113

D. Etika Bisnis Islam Dalam Pengembangan Usaha...............115

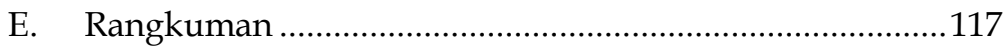

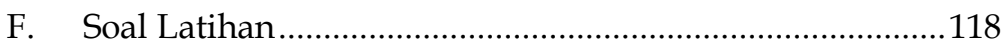

BAB IX Manajemen Strategik Dalam Organisasi .......................119

A. Manajemen Strategi Dalam Organisasi Profit ....................120

B. Manajemen strategi Dalam Organisasi Non Profit............122

C. Faktor-faktor yang Berpengaruh dalam Manajemen

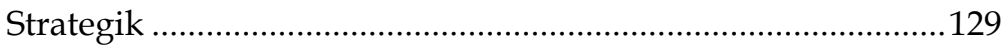

D. Risiko Manajemen Strategik Pada Organisasi.....................131

E. Dimensi Manajemen Strategik Pada Organisasi ................132

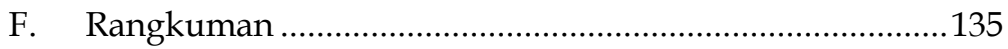

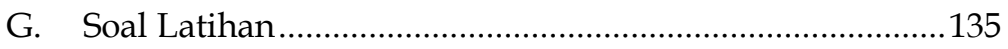

BAB X Pengawasan, Evaluasi Dan Umpan Balik Strategik ....136

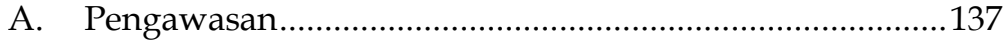

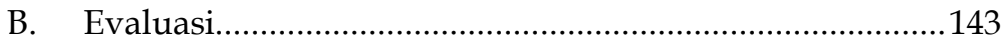

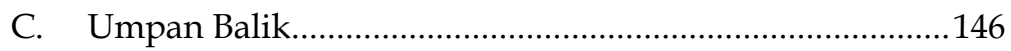

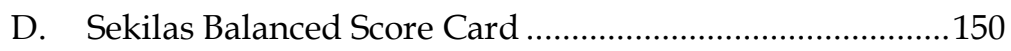

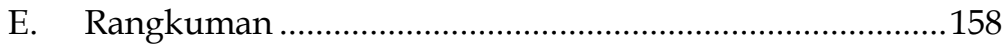

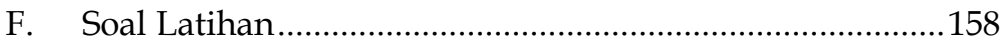

BAB XI Sekilas Strategi Samudra Biru (Blue Ocean Strategy)....160

A. Pengertian Blue Ocean Strategy ……………………….......161

B. Prinsip Strategi Samudra Biru (Blue Ocean Strategy) ........162

C. Strategi Samudra Biru (Blue Ocean Strategy).......................164

D. Tinjauan Strategi Samudra Biru (Blue Ocean Strategy)......167 
E. Kerangka Kerja dan Alat Analisis Samudera Biru ............ 168

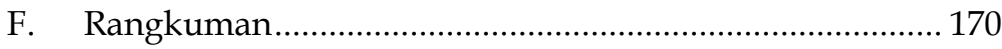

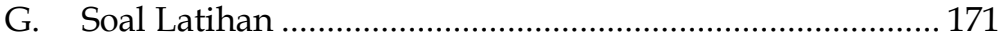

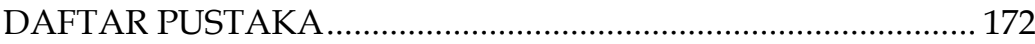

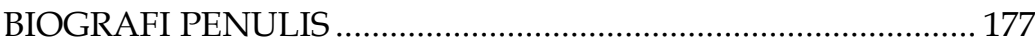




\section{PENDAHULUAN}

Buku bahan ajar mengenai manajemen strategik ini, secara khusus dibuat dalam rangka memberikan bahan-bahan belajar untuk mahasiswa dalam mata kuliah manajemen strategik. Diharapkan dengan buku bahan ajar ini mampu secara komprehensif memberikan konsep-konsep manajemen strategik pada semua mahasiswa. Dalam bidang ekonomi khususnya di lingkungan bisnis yang mengembangkan manajemen secara teoritis dan praktis, Manajemen Strategik telah cukup lama dikenal dan dikembangkan. Hakikat dari strategi dan kebijakan bisnis akan bisa diraih melalui pemahaman secara mendalam tentang definisi yang dikemukakan oleh berbagai pakar. Sehingga dapat memberikan kajian-kajian secara sistematis dalam pembelajaran manajemen strategik di ruang kelas. Strategi dan kebijakan bisnis merupakan keputusan yang dibuat pada level manajemen puncak. Keputusan yang bersifat menyeluruh ini akan mendasari berbagai keputusan yang bersifat strategis dan tentunya sangat memerlukan kecermatan dalam merumuskan ataupun menjabarkannya.

Dengan merumuskan strategi, berarti perusahaan telah membuat formulasi tentang apa yang harus dilakukan dalam bisnis. Penjabarannya diperlukan agar strategi dan kebijakan tersebut lebih mudah untuk diaplikasikan. Dalam pengertian umum, istilah manajemen strategi dan kebijakan bisnis sering menjadi rancu. Para mahasiswa acap kali mengalami kesulitan untuk membedakan antara strategi korporat (strategi pada level puncak perusahaan) dan strategi fungsional di bidang pemasaran. Apalagi, intensitas topik yang disajikan di berbagai media massa Indonesia memang lebih banyak berbicara tentang strategi pemasaran daripada strategi pada level manajemen puncak. Oleh karena itu, sebagai langkah awal untuk memahami perkuliahan ini, mahasiswa perlu menguasai proses, konten, serta konteks strategi dan kebijakan bisnis. Bukua bahan ajar ini dilengkapi dengan gambaran secara menyeluruh tentang konsep manajemen strategi dan kebijakan bisnis dalam perspektif pemikiran yang 
dikemukakan oleh berbagai pakar kebijakan bisnis. Setelah mempelajari buku bahan ajar ini, mahasiswa diharapkan mampu menjelaskan konsep manajemen strategi dan kebijakan bisnis.

Pengimplementasian Manajemen Strategik di lingkungan organisasi bidang bisnis didasari oleh falsafah yang berisi nilainilai persaingan bebas antar organisasi bisnis sejenis, melalui pendayagunaan semua sumber yang dimiliki untuk mencapai tujuan yang bersifat strategik. Tujuan tersebut adalah mempertahankan dan mengembangkan eksistensi masing-masing untuk jangka waktu panjang, melalui kemampuan meraih laba kompetitif secara berkelanjutan. Di era revolusi industry $4.0 \mathrm{ini}$, diharapkan dengan buku ajar ini mahasiswa terbuka wawasannya dalam melihat berbagai peta persaingan dalam berbagai organisasi. Sehingga sangat penting mahasiswa memahami pengelolaan organisasi dengan pendekatan manajemen strategik dalam rangka mengoptimalkan alternatif-alternatif strategi dalam mencapai tujuan organisasi bukan hanya pada tataran jangka pendek dan menengah tetapi sampai pada jangka panjang.

Akhir kata, semoga buku bahan ajar manajemen strategik ini dapat berkontribusi dalam pengembangan konsep-konsep manajemen strategik yang dapat digunakan oleh mahasiswa dalam rangka mengoptimalkan setiap potensi dirinya untuk membangun sumber daya manusia yang unggul dan berdaya saing dengan memfasilitasi bahan ajar yang adaptif dengan kebutuhan dirinya dan kebutuhan industri kerja. 
MANAJEMEN STRATEGIK TEORI DAN IMPLEMENTASI 


\section{BAB I \\ Ruang Lingkup dan Kebijakan \\ Manajemen Strategik}

\section{A. Pengertian Manajemen Strategik}

Dalam mencapai sebuah tujuan dibutuhkan strategi yang tepat dalam mencapainya. Semua organisasi memiliki strategi dalam rangka mencapai tujuan organisasinya. Hal ini menjadi pertimbangan bagi semua organisasi untuk memiliki strategi yang tepat. Kata "strategi" berasal dari bahasa Yunani, yaitu "strategos" (stratos = militer dan ag = memimpin), yang berarti "generalship" atau sesuatu yang dikerjakan oleh para jenderal perang dalam membuat rencana untuk memenangkan perang. Secara umum, strategi sebagai cara mencapai tujuan. Strategi merupakan rencana jangka panjang untuk mencapai tujuan.

\section{success}

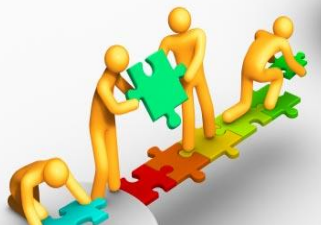

Gambar 1.1. Ilustrasi Manajemen Strategik

Bila suatu organisasi mempunyai suatu "strategi", maka strategi itu harus mempunyai bagian-bagian yang mencakup unsur-unsur strategi. Menurut Rachmat (2014:2) suatu "strategi" mempunyai 5 (lima) unsur, yaitu :

1. Gelanggang aktivitas atau Arena merupakan area (produk, jasa, saluran distribusi, pasar geografis, dan lainnya) di mana organisasi beroperasi. Unsur Arena tersebut seharusnya tidaklah bersifat luas cakupannya atau terlalu umum, akan tetapi perlu lebih spesifik, seperti kategori 
produk yang ditekuni, segmen pasar, area geografis dan teknologi utama yang dikembangkan, yang merupakan tahap penambahan nilai atau value dari skema rantai nilai, meliputi perancangan produk, manufaktur, jasa pelayanan, distribusi dan penjualan.

2. Sarana kendaraan atau Vehicles yang digunakan untuk dapat mencapai arena sasaran. Dalam penggunaan sarana ini, perlu dipertimbangkan besarnya risiko kegagalan dari penggunaan sarana. Risiko tersebut dapat berupa terlambatnya masuk pasar atau besarnya biaya yang sebenarnya tidak dibutuhkan atau tidak penting, serta kemungkinan risiko gagal secara total.

3. Pembeda yang dibuat atau differentiators, adalah unsur yang bersifat spesifik dari strategi yang ditetapkan, seperti bagaimana organisasi akan dapat menang atau unggul di pasar, yaitu bagaimana organisasi akan mendapat pelanggan secara luas. Dalam dunia persaingan, kemenangan adalah hasil dari pembedaan, yang diperoleh dari fitur atau atribut dari suatu produk atau jasa suatu organisasi, yang berupa citra, kustomisasi, unggul secara teknis, harga, mutu atau kualitas dan reabilitas, yang semuanya dapat membantu dalam persaingan.

4. Tahapan rencana yang dilalui atau staging, merupakan penetapan waktu dan langkah dari pergerakan stratejik. Walaupun substansi dari suatu strategi mencakup arena, sarana/vehicles, dan pembeda, tetapi keputusan yang menjadi unsur yang keempat, yaitu penetapan tahapan rencana atau staging, belum dicakup. Keputusan pentahapan atau staging didorong oleh beberapa faktor, yaitu sumber daya (resource), tingkat kepentingan atau urgensinya, kredibilitas pencapaian dan faktor mengejar kemenangan awal.

5. Pemikiran yang ekonomis atau economic logic, merupakan gagasan yang jelas tentang bagaimana manfaat atau keuntungan yang akan dihasilkan. Strategi yang berhasil, tentunya mempunyai dasar pemikiran yang ekonomis, 
sebagai tumpuan untuk penciptaan keuntungan yang akan dihasilkan.

Menurut Goldworthy dan Ashley (1996:98) mengemukakan ada 7 (tujuh) aturan dasar dalam merumuskan suatu strategi sebagai berikut :

1. Ia harus menjelaskan dan menginterpretasikan masa depan, tidak hanya masa sekarang.

2. Arahan strategi harus bisa menentukan rencana dan bukan sebaliknya.

3. Strategi harus berfokus pada keunggulan kompetitif, tidak semata-mata pada pertimbangan keuangan.

4. Ia harus diaplikasikan dari atas ke bawah, bukan dari bawah ke atas.

5. Strategi harus mempunyai orientasi eksternal.

6. Fleksibilitas adalah sangat esensial.

7. Strategi harus berpusat pada hasil jangka panjang.

Fungsi dari strategi pada dasarnya adalah berupaya agar strategi yang disusun dapat diimplementasikan secara efektif. Menurut Sofyan Assauri (2013) terdapat enam fungsi yang harus dilakukan secara simultan, yaitu :

1. Mengkomunikasikan suatu maksud (visi) yang ingin dicapai kepada orang lain. Strategi dirumuskan sebagai tujuan yang diinginkan, dan mengkomunikasikan, tentang apa yang akan dikerjakan, oleh siapa, bagaimana pelaksanaan pengerjaannya, untuk siapa hal tersebut dikerjakan, dan mengapa hasil kinerjanya dapat bernilai. Untuk mengetahui, mengembangkan dan menilai alternatif-alternatif strategi, maka perlu dilihat sandingan yang cocok atau sesuai antara kapabilitas organisasi dengan faktor lingkungan, di mana kapabilitas tersebut akan digunakan.

2. Menghubungkan atau mengaitkan kekuatan atau keunggulan organisasi dengan peluang dari lingkungannya. 
3. Memanfaatkan atau mengeksploitasi keberhasilan dan kesuksesan yang didapat sekarang, sekaligus menyelidiki adanya peluang-peluang baru.

4. Menghasilkan dan membangkitkan sumber-sumber daya yang lebih banyak dari yang digunakan sekarang. Khusunya sumber dana dan sumber-sumber daya lain yang diolah atau digunakan, yang penting dihasilkannya sumber-sumber daya nyata, tidak hanya pendapatan, tetapi juga reputasi, komitmen karyawan, identitas merek dan sumber daya yang tidak berwujud lainnya.

5. Mengkoordinasikan dan mengarahkan kegiatan atau aktivitas organisasi ke depan. Strategi harus menyiapkan keputusan yang sesuai dan sangat penting bagi upaya untuk pencapaian maksud dan tujuan organisasi.

6. Menanggapi serta bereaksi atas keadaan yang baru dihadapi sepanjang waktu. Proses yang terus-menerus berjalan bagi penemuan maksud dan tujuan untuk menciptakan dan menggunakan sumber sumber daya, serta mengarahkan aktivitas pendukungnya.

Menurut Rachmat (2014:143), mendefinisikan tipe strategi sebagai strategi alternatif yang dapat dikejar perusahaan. Jika perusahaan menjalankan beberapa strategi risiko sekaligus, hal tersebut dapat menjadi sangat berisiko. Maka, perusahaan harus mengutamakan prioritas dan sumber daya terbatas yang dimiliki perusahaan.

1. Strategi Integrasi

Strategi integrasi ke depan, integrasi ke belakang, dan integrasi horizontal secara kolektif disebut sebagai integrasi vertikal (vertical integration). Integrasi vertikal memungkinkan sebuah perusahaan memperoleh kendali atas distributor, pemasok (supplier), dan pesaing.

a. Strategi integrasi ke depan

Berkaitan dengan usaha untuk memperoleh kepemilikan atau kendali yang lebih besar atas distributor.

b. Strategi integrasi ke belakang 
Strategi yang mengupayakan kepemilikan atau kendali yang lebih besar atas pemasok perusahaan. Strategi tersebut sangat tepat ketika pemasok perusahaan yang ada saat ini tidak bisa diandalkan, terlampau mahal, atau tidak mampu memenuhi kebutuhan perusahaan.

c. Strategi integrasi horizontal

Strategi yang mengupayakan kepemilikan atau kendali yang lebih besar atas pesaing perusahaan. Merger, akuisisi, dan pengambilan di antara pesaing memungkinkan peningkatan skala ekonomi serta mendorong transfer sumber daya dan kompetensi.

2. Strategi Intensif

Terbagi menjadi analisis strategi ke dalam pasar dan produk. Dapat digunakan pada saat menentukan strategi atas produk baru atau penawaran produk baru di pasar yang ada ataupun pasar yang baru. Penetrasi pasar, pengembangan pasar, dan pengembangan produk disebut sebagai strategi intensif untuk meningkatkan posisi kompetitif suatu perusahaan dengan produk yang ada saat ini.

a. Strategi penetrasi pasar

Penetrasi pasar adalah strategi yang mengusahakan peningkatan pangsa pasar untuk produk atau jasa yang ada di pasar saat ini melalui upaya pemasaran yang lebih besar.

b. Strategi pengembangan pasar

Pengembangan pasar meliputi pengenalan produk atau jasa yang ada saat ini ke wilayah-wilayah geografis yang baru.

c. Strategi pengembangan produk

Strategi yang mengupayakan peningkatan penjualan dengan cara memperbaiki atau memodifikasi produk atau jasa yang ada saat ini.

3. Strategi diversifikasi

Ada dua tipe umum strategi diversifikasi, yaitu terkait dan tidak terkait. Dikatakan terkait apabila rantai 
nilai bisnis memiliki kesesuaian strategik lintas bisnis yang bernilai secara kompetitif. Bisnis dikatakan tidak terkait apabila rantai nilai bisnis yang bernilai secara kompetitif yang terbagi menjadi dua yaitu horizontal ditujukan kepada customer yang sudah ada dan conglomerate ditujukan bagi customer baru.

4. Strategi Defensif

Perusahaan dapat melakukan penciutan, divestasi, dan likuidasi. Penciutan terjadi apabila perusahaan melakukan pengelompokan ulang melalui pengurangi biaya dan aset untuk membalik penjualan dan laba yang menurun. Divestasi adalah menjual satu divisi atau bagian dari suatu perusahaan. Divestasi dapat menjadi bagian dari keseluruhan strategi penciutan untuk membebaskan organisasi dari bisnis yang tidak lebih menguntungkan, yang membutuhkan terlalu banyak modal atau yang tidak begitu sesuai dengan aktivitas perusahaan yang lain. Likuidasi adalah menjual seluruh aset perusahaan secara terpisah-pisah untuk kekayaan berwujudnya.

Adapun menurut Whelen dan Hunger (2008:15) ada beberapa tingkatan dalam strategi untuk perusahaan besar. Ada tiga tingkatan strategi manajemen yang berkembang sesuai dengan perkembangan perusahaan yakni sebagai berikut :

\section{Strategi Korporasi (Corporate Strategy)}

Ini adalah strategi yang mencerminkan seluruh arah perusahaan yang bertujuan menciptakan pertumbuhan bagi perusahaan secara keseluruhan dan bagi manajemen berbagai macam bisnis lini produk. Ada tiga jenis strategi yang dapat dipakai pada tingkat strategi ini, yaitu:

a) Strategi pertumbuhan (growth strategy)

Strategi yang berdasarkan pada tahap pertumbuhan yang sedang dilalui perusahaan

b) Strategi stabilitas (stability strategy)

Strategi dalam menghadapi kemerosotan penghasilan yang sedang dihadapi oleh suatu perusahaan 
c) Retrenchment strategy

Strategy yang diterapkan untuk memperkecil atau mengurangi usaha yang dilakukan perusahaan

2. Strategy Bisnis (Business Strategy)

Strategy ini digunakan pada tingkat produk atau unit bisnis dan merupakan strategi yang menekankan pada perbankan posisi bersaing produk atau jasa pada spesifikasi atau segmen pasar tertentu. Terdapat tiga macam strategi yang bisa digunakan pada strategi tingkat bisnis ini, yaitu Strategi kepemimpinan biaya, Strategi diferensiasi, dan Strategi focus. Strategi pada tingkat ini dirumuskan dan ditetapkan oleh para manajer yang diserahi tugas tanggung jawab oleh manajemen puncak atau mengelola bisnis bersangkutan.

3. Strategi Fungsional (Fungsional Strategy)

Strategi ini digunakan pada level fungsional seperti operasional, pemasaran, keuangan, dan sumber daya manusia. Strategi ini mengacu pada dua tingkatan strategi sebelumnya yaitu strategi korporasi dan strategi bisnis. Strategi fungsional juga disebut sebagai value-basedstrategy. Berfokus pada memaksimumkan produktivitas sumber daya yang digunakan dalam memberikan value terbaik untuk pemenuhan kebutuhan pelanggan.

Menurut Hoesada (2013) manajemen adalah istilah yang bermakna manusia atau kumpulan manusia yang melakukan kegiatan manajemen, yang terpisah dari pekerja (labor) sebagai SDM yang dikelola manajemen. Istilah manajemen berasal dari kata kerja to manage berarti kontrol. Dalam bahasa Indonesia dapat diartikan mengendalikan, menangani atau mengelola. Selanjutnya kata benda manajemen dapat mempunyai berbagai arti. Pertama ialah sebagai pengelolaan, pengendalian, atau penanganan (managing). Kedua ialah sebagai perlakuan secara terampil untuk menangani sesuatu berupa skillfull treatment. Ketiga, merupakan gabungan dari pengertian di atas adalah 
pengelolaan bentuk kerja sama dalam mencapai tujuan tertentu.

Tiga pengertian tersebut mendukung kesepakatan anggapan bahwa manajemen dapat dipandang sebagai ilmu dan seni. Manajemen sebagai ilmu artinya manajemen memenuhi kriteria ilmu dan metode keilmuan yang menekankan kepada konsep-konsep, teori, prinsip dan teknik pengelolaan. Adapun menurut Salusu (2003:85) manajemen strategik terdiri dari dua kata yaitu manajemen dan strategi. Manajemen sepeti yang dibahas diatas berarti peraturan atau pengelolaan. Sedangkan strategi menurut bahasa yunani strategos atau strategeus dengan kata jamak strategi. Strategeus berarti jenderal, namun dalam yunani kuno sering berarti perwira Negara (state office) dengan fungsi yang luas.

Menurut David (2011:5), manajemen strategis dapat didefinisikan sebagai seni dan pengetahuan dalam merumuskan, mengimplementasikan, serta mengevaluasi keputusan-keputusan lintas fungsional yang memampukan sebuah organisasi mencapai tujuannya. Manajemen strategis berfokus pada usaha untuk mengintegrasikan manajemen, pemasaran, keuangan atau akuntansi, produksi atau operasi, penelitian dan pengembangan, serta sistem informasi komputer untuk mencapai keberhasilan organisasional. Sedangkan menurut Thomas L Wheelen dan J. David Hunger (2003), manajemen strategis adalah serangkaian keputusan manajerial dan tindakan yang menentukan kinerja jangka panjang dari perusahaan. Ini mencakup pemindaian lingkungan (baik eksternal dan internal) perumusan strategi (strategy atau perencanaan jangka panjang) pelaksanaan dan evaluasi pengendalian strategy.

Dari penjelasan diatas, dapat diambil kesimpulan bahwa manajemen strategik adalah suatu ilmu dalam pembuatan keputusan yang dibuat oleh manajemen puncak dan di laksanakan oleh seluruh jajaran dalam sebuah organisasi untuk mencapai tujuannya. Hal itu akan membentuk sebuah strategi menentukan arah dan langkah- 
langkah selanjutnya yang akan dipakai untuk kemajuan perusahaan tersebut. Oleh karena itu, diperlukan adanya pemikiran-pemikiran serius dan mumpuni untuk mengatur strategi.

Hunger dan Wheelan (2003), menjelaskan perkembangan konsep manajemen strategik melalui 5 (lima) tahap sebagai berikut :

1. Perencanaan keuangan dasar: pada tahap ini manajer mulai membuat perencanaan yang serius terutama pada saat mereka diminta mengajukan anggaran yang serius untuk tahun berikutnya.

2. Perencanaan berbasis peramalan: karena pembuatan anggaran tahunan dianggap kurang berguna dalam menstimulasi perencanaan jangka panjang, maka para manajer selanjutnya berupaya untuk mengajukan rencana dalam waktu lima tahun mendatang.

3. Perencanaan strategis: frustasi dengan situasi konflik politik di dalam perusahaan, sementara pada saat yang sama diperoleh suatu kenyataan bahwa rencana lima tahunan yang dibuat tidak berjalan efektif, maka manajemen puncak kemudian mengambil kendali terhadap proses perencanaan dengan memulai kegiatan perencanaan strategis.

4. Manajemen strategis: menyadari bahwa rencana strategis terbaikpun tidak akan berguna tanpa adanya input dan komitmen dari manajer di level yang lebih rendah, maka manajer puncak pada tahap selanjutnya membentuk kelompok perencanaan yang terdiri dari para manajer dan karyawan kunci pada berbagai jenjang manajemen yang berasal dari berbagai departemen dan kelompok kerja. Mereka mengembangkan dan mengintegrasikan serangkaian rencana strategis dengan tujuan mencapai tujuan utama perusahaan.

5. Konsep manajemen strategis memperoleh momentum keberhasilan sebagai model pengembangan strategi perusahaan di era tahun 1990-an di mana banyak 